\title{
Adaptation of Teachers' Conceptions and Practices of Formative Assessment Scale into Turkish Culture and a Structural Equation Modeling*
}

Pınar Karaman ${ }^{a,{ }^{* *}}$, Çavuş Şahin ${ }^{b}$

\begin{tabular}{lrl}
\hline Received: & 21 October 2017 \\
Revised: & 28 November 2017 \\
Accepted: & 30 November 2017 \\
ISSN: 1307-9298 \\
Copyright $\odot$ IEJEE \\
www.iejee.com
\end{tabular}

DOI: $10.26822 /$ iejee.2017236114

\begin{abstract}
The purpose of this study was to adapt Teachers' Conceptions and Practices of Formative Assessment Scale (TCPFS) based on the Theory of Planned Behavior (TPB) into Turkish culture and apply the TPB to examine teachers' intentions and behaviors regarding formative assessment. After examining linguistic validity of the scale, Turkish scale was applied to 400 primary school teachers in Turkey. Confirmatory factor analysis (CFA) was administered for the construct validity. The results showed that the model had fairly good model fit (RMSEA $=.07, \mathrm{CFI}=.90, \mathrm{TLI}=.87, \mathrm{IFI}=.90$ ). Reliability of the Turkish version of the scale was attained through Cronbach's alpha coefficient. Findings revealed that adapted scale has satisfactory psychometric features. Since the psychometric properties of the scale in the TPB were acceptable, predictive model was estimated. Structural equation modeling was used to examine the applicability of TPB in understanding teachers' conceptions and practices of formative assessment. The results supported that TPB model can help to predict and explain teachers' conceptions and behaviors regarding formative assessment.
\end{abstract}

Keywords: Formative assessment; teachers; theory of planned behavior.

\section{Introduction}

Today, assessment is not only used for accountability purposes but also used for shaping ongoing instruction in the classroom (Darling-Hammond \& Pecheone, 2010; Gong, 2010; Wilson \& Draney, 2004). This assessment approach called as assessment for learning approach or formative assessment is intended to give information about student learning (Black \& William, 2006; Heritage, 2010a; Shepard, 2000). Therefore, it distinguishes from diagnostic assessment approach used to identify students and summative assessment approach used to make final judgment of student competency (Trumbull \& Lash, 2013). Formative assessment approach based on cognitive theory and sociocultural theory provides several activities: giving continuous feedback, promoting students' participation, making instructional changes in the classroom (Black \& Wiliam, 1998; NCTE, 2013; Shermis \& Di Vesta, 2011). Since this type of assessment is to shape or help students' learning during the learning process, it is called as a process during ongoing instruction (Black \& William, 1998; Frohbeiter, Greenwald, Stecher, \& Schwartz, 2011; Sadler, 1998). Heritage (2007) also defined formative assessment as in four core elements: facilitating student learning, meaningful feedback, student involvement, and learning progressions. Many studies addressed that formative assessment practices have positive effect on students' learning and attainment (Bennett, 2011; Hattie, 2009; Heritage, 2010b; Ruiz-Primo \& Furtak, 2006; Sadler, 1998; Sumantri \& Satriani, 2016; Jonsson, Lundahl, \& Holmgren, 2015; Volante \& Beckett, 2011). Therefore, assessment for learning as part of the education reform has been largely focused in many countries such as UK, Australia, Hong Kong, New Zealand, USA etc. The new assessment culture has also been placed in Turkey's current curriculum (MoNE, 2013).

However implementation of educational reforms in schools is a challenging and complex process (Fullan, 1999). Teachers have a major role for achieving educational change (Carles, 2015; Knight, 2002). Teachers' educational philosophies and their conceptions consisted of their beliefs, attitudes, and intentions may have important effect on their behaviors in the classroom (Brown, 2004; Pajares, 1992; Harrison, 2013; Haney \& McArthur, 2002; Woolfolk Hoy, Davis, \& Pape, 2006). Specifically the quality of assessment for learning approach or formative assessment implementation may rely heavily on beliefs, attitudes, and intentions that teachers have (Brown, Harris, \& Harnett, 2012). Several research has been done about teachers' beliefs, attitudes, and practices regarding formative assessment (Carles, 2015; Brown \& Gao, 2015; Brown, Kennedy, Fok, Chan, \& Yu, 2009; Davis \& Neitzel, 2011; Young \& Jackman, 2014; Yau, 2004). In Turkey, the research about teachers' formative assessment beliefs, attitudes or practices were very limited (Aydoğmuş \& Keskin, 2012; Konur \& Konur, 2011; Öz, 2014; Sönmez Ektem \& Erben Keçici, \& Pilten, 2016). Most of the studies related with teachers' attitudes, beliefs or practices regarding formative assessment focused on only one aspect of assessment but relationship between these variables under a theoretical framework has not been extensively investigated (Yan \& Cheng, 2015).

\footnotetext{
*This study was orally presented at the Ninth International Congress of Educational Research on 11-14 May, 2017 held in Ordu University, Turkey a, ${ }^{*}$ Corresponding author: Pınar KARAMAN, Sinop University, Faculty of Education, Department of Educational Sciences, Sinop/Turkey. E-mail: pkaraman1626@gmail.com

${ }^{b}$ Çanakkale Onsekiz Mart University, Faculty of Education, Department of Primary Education, Çanakkale/Turkey. E-mail: csahin25240@yahoo.com
} 


\section{Theory of planned behavior}

Theory of planned behavior (TPB) as an explanatory model proposed by Ajzen $(1985,1991)$ explains human behavior's intention to perform actual behavior (Figure 1). The theory gives the relationships among attitude, subjective norms, perceived behavioral control, intention, and behavior. According to the theory, a person with more favorable attitude, subjective norm, and perceived behavioral control will more likely to have intention to perform behavior. Bandura's (1997) self-efficacy theory used as an indicator of perceived difficulty also has been used in TPB model (e.g. Martin \& Kulinna, 2004; Tery \& O'Leary, 1995; Yan \& Cheng, 2015).

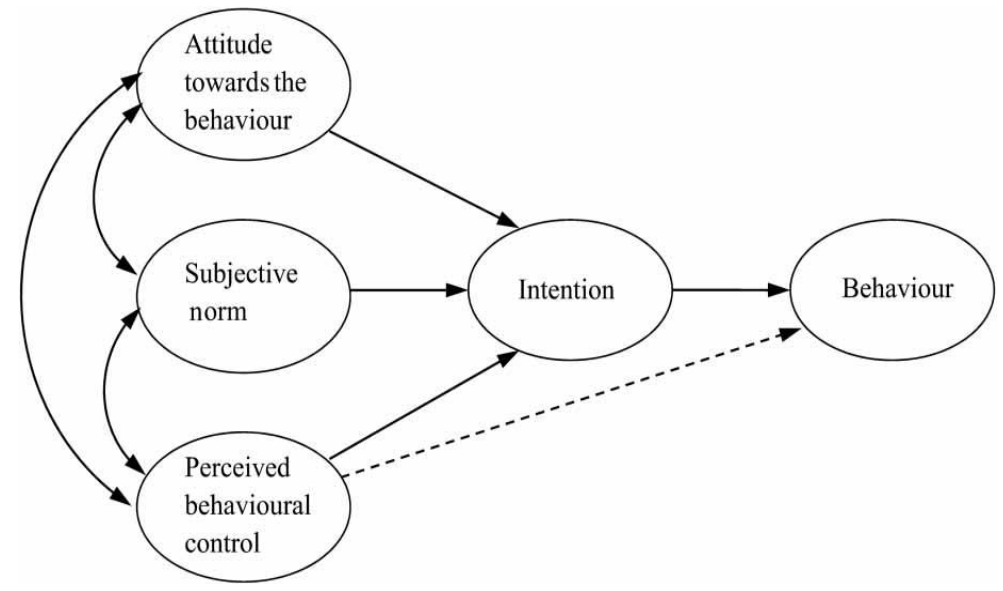

Figure 1. Theory of planned behavior (Ajzen, 1991)

TPB suggests that four factors impact on individuals' behaviors: (a) intentions, (b) attitudes, (c) subjective norm, (d) perceived behavioral control has both an indirect (via intentions) and direct impact.

The power of TPB model to predict and understand human behaviors was examined in many fields (e.g., Conner, Warren, Close, Sparks, 1999; Conatser, Block, \& Gansneder, 2002; Huchting, Lac, \& LaBrie, 2008; Martin \& Kulinna, 2005; Schifter \& Ajzen, 1985). TPB has also been used to understand teachers' attitudes, intentions, and behaviors (Crawley, 1990; Zint, 2002; Kersaint, Lewis, Potter, \& Meisels, 2007; Stanec, 2009). However, there are a few studies which used TPB to investigate teachers' conceptions and behaviors regarding assessment (e.g., Yan, 2014; Yan \& Cheng, 2015; Yim \& Cho, 2016). Since very limited studies have specifically investigated teachers' formative assessment conceptions and practices in the TPB model (e.g., Yan \& Cheng, 2015), more empirical research in that field is important.

The purpose of study was twofold. Firstly, adaptation of the Teachers' Conceptions and Practices of Formative Assessment Scale (TCPFS) developed by Yan and Cheng (2015) to Turkish was conducted in the study. Since the TCPFS scale based on TPB model provided specifically the prediction and explanation of teachers' intentions and practices regarding formative assessment, adaptation of the scale into Turkish culture is very important. With adapted scale, Turkish teachers' attitudes, intentions, and practices regarding formative assessment under a theoretical framework will be investigated extensively in empirical research. Therefore, the TCPFS scale in Turkish version will contribute to the relevant literature in Turkey. In the second part of the study, applicability of TPB was examined to understand the relationships among teachers' attitudes, intentions, and practices of formative assessment.

\section{Methodology}

Adaptation of an instrument is a complex task. The process of translation, adaptation and validation of an instrument for use in other cultures and languages requires rigorous planning and most appropriate methodology (Bracken \& Barona, 1991; Brislin, 1970). In the first phase of the study, validity and reliability of Turkish version of TCPS scale was examined. In the second phase of the study, predictive model was examined by using structural equation modeling (SEM).

\section{Participants}

In this study, "Teachers' Conceptions and Practices of Formative Assessment Scale (TCPFS)" was carefully adapted and tested to ensure its relevance to teachers in Turkey. The sample consisted of 400 primary teachers working at public schools in the province of Çanakkale and Sinop in Turkey.

\section{Instrument}

TCPFS has been developed by Yan and Cheng (2005) for measuring primary teachers' conceptions and practices of formative assessment. The questionnaire consisted of 40 items and seven scales in the TPB model regarding formative assessment. The instrument had affective attitude scale (AAT) with 7 items, instrumental attitude scale (IAT) with 13 items, subjective norm scale (SNO) with 5 items, controllability scale (CON) with 4 items, selfefficacy scale (SEF) with 6 items, intention scale (INT) with 6 items, and behavior scale (BEH) with 2 items. Rasch analysis and path analysis were used for examining the psychometric properties of the scale. The result of the analyses indicated a satisfactory fit between proposed model and observed data (Explained variance: $51 \%$, chisquare statistic $\chi 2=7.678, p>0.05$; RMSEA $=.059$; GFI= .995; $\mathrm{CFI}=$.997; $\mathrm{TLI}=$.971). Therefore, the instrument developed by Yan and Cheng (2005) using TPB as a 
theoretical framework regarding formative assessment was psychometrically robust enough.

\section{Procedure}

The adaptation of the TCPF scale into Turkish was done in accordance with Hambleton's (2005) suggestions. Hambleton's (2005) suggestions about five essential stages for instrument adaptation were considered in this study:

1. Original instrument was translated into Turkish by two bilingual translators who are familiar with the subject. These two translators produced the initial translations independently.

2. After the two versions of the translated instrument by two bilingual translators, these translations were compared and examined. With this examination, translated versions were compared with the original instrument in terms of their semantic, idiomatic, experiential, and conceptual equivalence. At the end of this process, researchers attained one single version of translated instrument.

3. The translated instrument was presented to the group of teachers $(N=10)$ to verify whether the items of the instrument were understandable for the intended group. The teachers expressed that the items of the instrument were clear and understandable.

4. Back translation was used. The translated version of the instrument was translated back into the source language by two translators other than first ones. Back translated version of the instrument and the original instrument were compared. The result showed that two versions were conceptually similar.

5. The instrument was piloted with a small group of teachers $(N=50)$. The instructions and items of the translated instrument were examined in this process. Pilot study result showed that the translated instrument was ready for the teachers as a target group. After administering the instrument to the participants, the psychometric properties of the instrument was examined by using recognized statistical analysis.

\section{Findings}

\section{Construct Validity}

In this study, confirmatory factor analysis was used to assess how well hypothesized measurement model data fit with observed data (Byrne, 2001; Tabachnick \& Fidell, 2013). In accordance with this aim, AMOS program was used for CFA. Since some items' factor loading values were less than .40, these items were eliminated from the scale (AAT7 item, IAT1 item, and SEF1item). After eliminating these items from the scale, CFA was runned again. The results of CFA fit indices showed the sufficiency of the model $\left(\chi^{2}=2301,272, d f=609 p<.001\right.$, RMSEA $=.08$, $\mathrm{CFI}=.86, \mathrm{TLI}=.85, \mathrm{IFI}=.86$ ). For RMSEA, .01, .05, and .08 values indicate excellent, good, and acceptable fit (MacCallum, Browne, \& Sugawara, 1996; Sümer, 2000). Therefore, the value of .08 for RMSEA was considered as acceptable fit. There are several goodness of fit indices for CFA such as CFI, TLI, NFI, IFI. The value of .90 was considered as adequate fit. And the value of .95 was considered as a perfect fit (Bentler \& Bonett, 1980; Şimşek, 2007). The goodness of fit indices in this study indicated the acceptable model fit. Besides, CFA suggested some modifications between some items. Some residuals were allowed to correlate since the variables had on the same factor (Landis, Edwards, \& Cortina, 2009). After the modifications between some items, the adjusted model showed that the model had fairly good model fit $\left(\chi^{2}=1906.27, d f=567, p<.001\right.$, RMSEA $=.07, \mathrm{CFI}=.90, \mathrm{TLI}=.87, \mathrm{IFI}=.90$ ). Results from CFA are presented in Figure 2.

\section{Reliability}

Reliability of the Turkish version of the TCPFS scale was attained through Cronbach's Alpha coefficient (Table 1). Internal consistency of the scale were found .95 for the "whole scale", .90 for AAT sub-factor, .93 for IAT sub-scale, .83 for SN sub-scale, .92 for CON sub-scale, .86 for SEF sub-scale, .93 for INT sub-scale and .86 for BEH sub-scale. The results showed that overall total scores and also subscales had good reliability.

Table 1. Cronbach's Alpha Reliability Coefficient for the TCPFS scale

\begin{tabular}{lr}
\hline Factors & Cronbach's Alpha \\
\hline Affective Attitude (AAT) & .90 \\
Instrumental Attitude (IAT) & .93 \\
Subjective Norm (SN) & .83 \\
Controllability (CON) & .92 \\
Self-Efficacy (SEF) & .86 \\
Intention (INT) & .93 \\
Behavior (BEH) & .86 \\
TCPF Scale & .95 \\
\hline
\end{tabular}

\section{Predictive Model}

Since the psychometric properties of the scale in the TPB model were acceptable, predictive (hypothesized) model was estimated by using structural equation modeling (Figure 3). Predictive model in the TPB framework helped to predict teachers' conceptions and behaviors regarding formative assessment in this study. The predictive (hypothesized) model demonstrated good fit $\left(\chi^{2}=2051.975, \quad d f=607, \quad p<.001, \quad\right.$ RMSEA=.07, $\quad C F I=.88$; $\mathrm{TLI}=.87, \quad \mathrm{IFI}=.88$ ). The analysis showed acceptable statistical fit between the proposed model based on Theory of Planned Behavior and the observed data. The standardized regression weights of the paths from instrumental attitude, self- efficacy and controllability to intention were significant $(p<.01)$. The strongest predictor of intention was self-efficacy $(\beta=.55)$, followed by controllability $(\beta=.16)$, and instrumental attitude $(\beta=.16)$. However standardized regression weight of the path from subjective norm ( $\beta=-.04)$, and affective attitude $(\beta=.07)$ to intention were not significant. The direct effect of intention and indirect effects of self-efficacy and controllability on behavior were also examined. In the predictive model, behavior (formative assessment practice) was predicted by both controllability $(\beta=-.52)$ 
and self-efficacy $(\beta=.68)$. However, standardized regression weight of the path from intention to behavior was not significant $(\beta=-.17)$. This model explained a substantial $71 \%$ of the variance in teachers' intentions and $15 \%$ of the variance in teachers' behaviors.

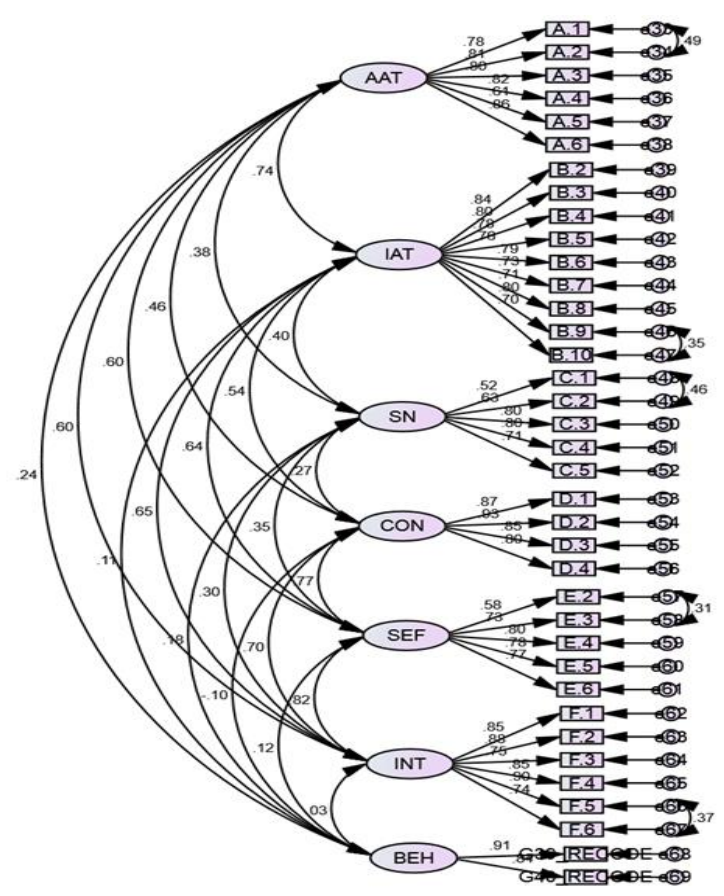

Figure 2. Confirmatory factor model based on the Theory of Planned Behavior

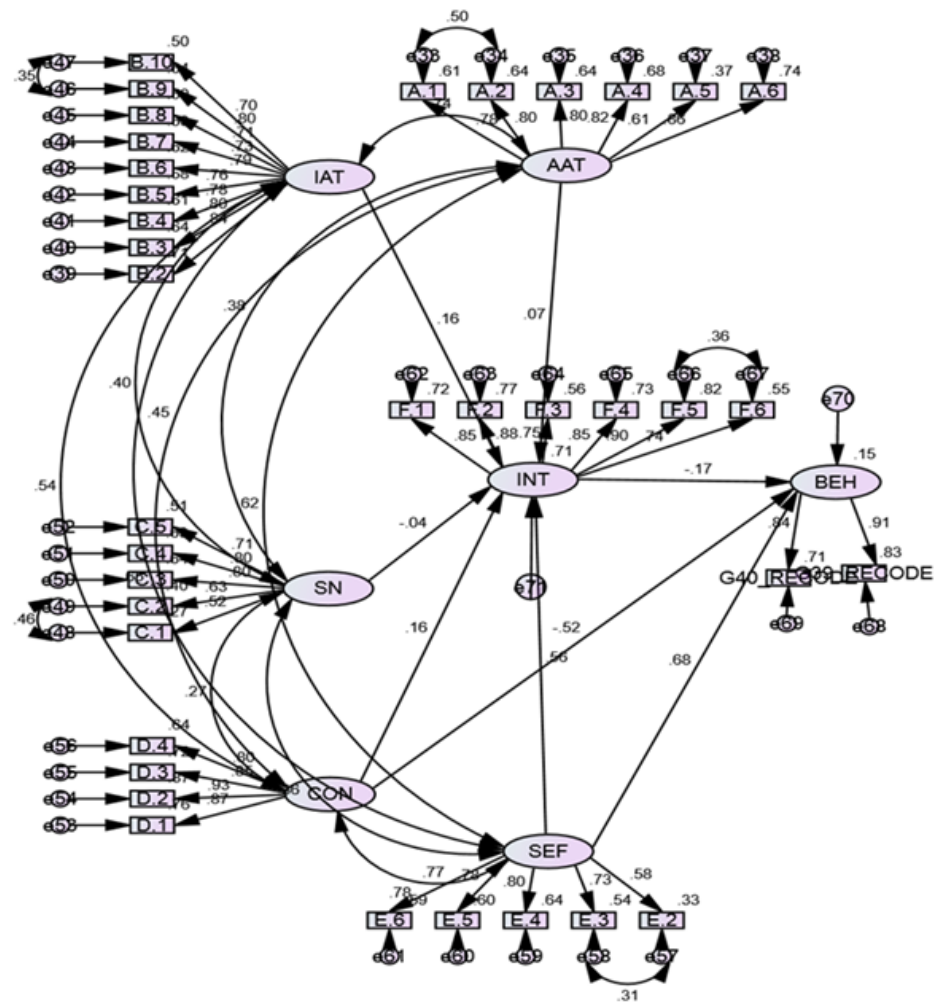

Figure 3. Predictive model of Theory of Planned Behavior 


\section{Discussion and Conclusion}

The purpose of this study was twofold: 1) to adapt 'Teachers' Conceptions and Practices of Formative Assessment Scale (TCPFS)" developed by Yan and Cheng (2015) to Turkish and examine psychometric features of the scale, 2) to apply the TPB model to examine teachers' conceptions and practices regarding formative assessment. First of all, linguistic validity of the scale was performed. The result showed that original version and Turkish version of the scale were quite similar in terms of linguistic fit. The translated instrument was applied to 400 primary school teachers for the construct validity of the scale. CFA was performed to examine whether the data support the proposed model of the scale. The fit index values of the structural model confirmed the construct validity of the scale. The reliability of the scale was examined with Cronbach's Alpha Coefficient. Reliability Coefficient indicated that the scale had good internal consistencies in the whole scale and also in the subscales. Therefore, validity and reliability of the adapted scale indicated that the scale has satisfactory psychometric features. In the current study, it was observed that some psychometric values for Turkish version of the scale were less than the values of original scale. These differences may occur while adapting educational and psychological instruments into different cultures and different languages (Hambleton, Merenda, \& Spielberger, 2005; Geisinger, 1994; Sireci \& Berberoğlu, 2000). In sum, adaptation and validation of the TCPFS scale to Turkish is important contribution to education research in Turkey. Given its parsimony and adequate fit, the adapted scale can be useful as a research and an assessment tool for measuring Turkish teachers' conceptions and practices of formative assessment.

In the second step of the study, the predictive model based on TPB was estimated. Structural equation modelling was used to examine the applicability of TPB in understanding teachers' conceptions and practices of formative assessment. The research results revealed that teachers' intentions to use formative assessment can be predicted by self-efficacy, perceived behavioral control, and instrumental attitude. Teachers' intentions were mostly predicted by self-efficacy. However, teachers' perceived behavioral control and instrumental attitude showed a weak impact on their intentions. This key finding was similar with research on TPB for teachers' assessment issues (Yan, 2014; Yan \& Cheng, 2015). In the Yan and Cheng's (2015) study, teachers' self-efficacy had a stronger effect on their intentions than instrumental attitude to conduct formative assessment. Yan (2014) focused on school-based assessment issue by using TPB model. The researcher also found that self-efficacy had a higher impact on teachers' intentions to conduct schoolbased assessment than instrumental attitude. Studies demonstrated that teachers' self-efficacy can affect their classroom activities and student achievement (Gibson \& Dembo, 1984), their teaching strategies (Allinder, 1994), and their attitudes toward new initiatives and reforms (Dixon \& Haigh, 2009; Fuchs, Fuchs, \& Bishop, 1992). The present study showed that teachers with higher level of self-efficacy tended to be more likely to conduct formative assessment. While self-efficacy, perceived behavioral control, and instrumental attitude were significant predictors of intention to conduct formative assessment, self-efficacy and perceived behavioral control were the significant predictors of formative assessment practices. Teachers' formative assessment behaviors were most strongly predicted by self-efficacy and strongly predicted by perceived behavioral control. The results showed that in general TPB model with self-efficacy has made great contribution to the prediction of intention and behavior. However, perceived behavioral control was less predictive than self-efficacy in the study. This finding was consistent with previous research on formative assessment conceptions and practices (Yan \& Chen, 2015).

In the present study, TPB model explained higher percentage of variance $(71 \%)$ in teachers' intentions to use formative assessment than in teachers' formative assessment practices (15\%). Meta-analytic studies about TPB showed that the model worked well for predicting and explaining intentions and behaviors (Armitage \& Conner, 2001; Notani, 1998; Sutton, 1998). Armitage and Conner (2001) analyzed 185 studies. They found that TPB model accounted, on average, 39\% of the variance in intention and $27 \%$ of the variance in behavior. In Sutton (1998)'s meta-analytic review, TPB and Theory of Reasoned Action model (TRA) was compared. The author found that TPB model was greater than TRA model for predicting and explaining of intentions and behaviors. These models explained $40-50 \%$ of variance in intention and $19-38 \%$ of the variance in behavior. The current finding was consistent with the previous TPB studies. In conclusion, this study supported that TPB model is an appropriate theoretical model for understanding factors that may predict and explain teachers' intentions and practices regarding formative assessment.

However, the study also had some limitations. Most important limitation of the study was that the findings based on self-report data from the primary teachers regarding formative assessment practices. Self-report data may increase the possibility of participant bias. In future studies, not only self-report data but also observational data from teachers regarding formative assessment practices might be considered. Another limitation of the study was to use convenience sampling that might affect the generalization of the study.

\section{References}

Ajzen, I. (1985). From intentions to actions: a theory of planned behavior. In J. Kuhl, \& J. Beckmann (Eds.), Action control: From cognition to behavior. Berlin: Springer Berlin Heidelberg.

Ajzen, I. (1991). The theory of planned behavior. Organizational Behavior and Human Decision Processes, 50(2), 179-211.

Allinder, R. (1994). The relationship between efficacy and the instructional practices of special education teachers and consultants. Teacher Education and Special Education, 17(2), 86-95.

Armitage, C. J., \& Conner, M. (2001). Efficacy of the theory of planned behaviour: a meta-analytic review. British Journal of Social Psychology, 40 (4), 471-499. 
Aydoğmuş, A. \& Coşkun Keskin, S. (2012). Use of process based measurement and evaluation tools by social sciences teachers: İstanbul province sample. Mersin University Faculty of Education Journal, 8 (2), 110-123.

Bandura, A. (1997). Self-efficacy: The exercise of control. New York, NY: W. H. Freeman and Company.

Beaton, D. E., Bombardier, C., Guillemin, F., \& Ferraz, M. B. (2000). Guidelines for the process of crosscultural adaptation of self-report measures. Spine, 25(24), 3186-3191.

Bennett, R. E. (2011). Formative assessment: A critical review. Assessment in Education: Principles, Policy \& Practice, 18(1), 5-25.

Bentler, P.M. \& Bonett, D.G. (1980). Significance tests and goodness of fit in the analysis of covariance structures. Psychological Bulletin, 88, 588-606.

Black, P., \& Wiliam, D. (1998). Assessment and classroom learning. Assessment in Education: Principles, Policy \& Practice, 5(1), 7-74.

Black, P., \& Wiliam, D. (2006). Assessment for learning in the classroom. In J. Gardner (Ed.), Assessment and learning, 9-25, SAGE Publication.

Brown, G. T. L. (2004). Teachers' conceptions of assessment: Implications for policy and professional development. Assessment in Education: Principles, Policy \& Practice, 11, 301-318.

Brown, G.T.L., Harris, L.R., \& Harnett, J. (2012). Teacher beliefs about feedback within an assessment for learning environment: Endorsement of improved learning over student well-being. Teaching and Teacher Education 28, 968-978.

Brown, G.T.L., \& Gao, L. (2015). Chinese teachers' conceptions of assessment for and of learning: Six competing and complementary purposes. Cogent Education, 2: 993836.

Brown, G. T. L., Kennedy, K. J., Fok, P. K., Chan, J. K. S., \& Yu, W. M. (2009). Assessment for improvement: Understanding Hong Kong teachers' conceptions and practices of assessment. Assessment in Education: Principles, Policy and Practice, 16(3), 347-363.

Bracken, B. A. \& Barona, A. (1991) State of the art procedures for translating, validating and using psychoeducational tests in crosscultural assessment. School Psychology International, 12 (1-2), 119-132.

Brislin, R. W. (1970) Back-translation for cross-cultural research. Journal of Cross-Cultural Psychology, 1 (3), 185-216.

Byrne B.M. (2001). Structural equation modeling with AMOS. Basic concepts, applications, and programming. Mahwah, N.J: Lawrence Erlbaum Associates.

Carles, D. (2015). Prospects for the implementation of assessment for learning. Assessment in Education, 12(1), 39-54
Crawley, F. E. (1990). Intentions of science teachers to use investigative teaching methods: A test of the theory of planned behavior. Journal of Research in Science Teaching. 277), 623-716.

Conatser, P., Block, M., \& Gansneder, B. (2002). Aquatic instructors' beliefs toward inclusion: The theory of planned behavior. Adapted Physical Activity Quarterly, $19,172-187$.

Conner, M., Warren, R., Close, S., \& Sparks, P. (1999). Alcohol consumption and theory of planned behavior: An examination of the cognitive mediation of past behavior. Journal of Applied Social Psychology, 29,1676-1704.

Darling-Hammond, L., \& Pecheone, R. (2010). Developing an internationally comparable balanced assessment system that supports high-quality learning. Princeton, $\mathrm{NJ}$ : Educational

Davis, D.S. \& Neitzel, C. (2011). A self-regulated learning perspective on middle grades classroom assessment, The Journal of Educational Research, 104(3), 202-215.

Dixon, H., \& Haigh, M. (2009). Changing mathematics teachers' conceptions of assessment and feedback. Teacher Development, 13(2), 173-186.

Ektem, I.S, \& Keçici, S.E., \& Pilten, G. (2016). Sınıf Öğretmenlerinin Süreç Odaklı Ölçme ve Değerlendirme Yöntemlerine illişkin Görüşleri, $A h i$ Evran Üniversitesi Kırşehir Eğitim Fakültesi Dergisi, $17(3), 661-680$

Frohbeiter, G., Greenwald, E., Stecher, B., \& Schwartz, H. (2011). Knowing and doing: What teachers learn from formative assessment and how they use information. CRESST Report 802. Los Angeles: UCLA National Center for Research on Evaluation, Standards, and Student Testing.

Fullan, M. (1999). Change forces: the sequel (London, Falmer Press)

Fuchs, L., Fuchs, D., \& Bishop, N. (1992). Instructional adaptations for students at risk. Journal of Educational Research, 86, 70-84.

Geisinger, K.F. (1994). Cross-cultural normative assessment: Translation and adaptation issues influencing the normative interpretation of assessment instruments. Psychological Assessment, 6(4), 304-312.

Gibson, S., \& Dembo, M. (1984). Teacher efficacy: A construct validation. Journal of Educational Psychology, 76(2), 569-582.

Gong, B. (2010). Using balanced assessment systems to improve student learning and school capacity: an introduction. Council of Chief State School Officers and Renaissance Learning.

Hambleton, R. K. (2005). Issues, designs, and technical guidelines for adapting tests into multiple languages and cultures. In R. K. Hambleton, P. F. Merenda, \& C. D. Spielberger (Eds.), Adapting educational and 
psychological tests for cross-cultural assessment (pp. 3-38). Mahwah, NJ: Lawrence Erlbaum.

Hambleton, R.K., Merenda, P.F., \& Spielberger, C.D. (2005). Adapting educational and psychological tests for cross-cultural assessment. Mahwah, NJ: Lawrence Erlbaum.

Haney, J. J., \& McArthur, J. (2002). Four case studies of prospective science teachers' beliefs concerning constructivist teaching practices. Science Education, 86, 783-802.

Harrison, C. (2013). Collaborative action research as a tool for generating formative feedback on teachers' classroom assessment practice: the KREST project. Teachers and Teaching: Theory and Practice, 19(2), 202-213.

Hattie, J. (2009). Visible learning: a synthesis of over 800 meta-analyses relating to achievement. London: Routledge.

Heritage, M. (2007). Formative Assessment: What Do Teachers Need to Know and Do? Phi Delta. Kappan, 89(2), 140-145.

Heritage, M. (2010a). Formative assessment: Making it happen in the classroom. Thousand Oaks, CA: Corwin Press.

Heritage, M. (2010b). Formative assessment and nextgeneration assessment systems: Are we losing an opportunity? Paper prepared for the Council of Chief State School Officers. Los Angeles: UCLA National Center for Research on Evaluation, Standards, and Student Testing (CRESST)

Herdman M, Fox-Rushby J, Badia X. (1998). A model of equivalence in the cultural adaptation of HRQoL instruments: the universalist approach. Qual Life Res, 7,323-335.

Huchting, K., Lac, A., \& LaBrie, J.W. (2008). An application of the theory of planned behavior to sorority alcohol consumption. Addictive Behavior, 33, 538-551.

Jonsson, A., Lundahl, C. \& Holmgren, A. (2015). Evaluating a large-scale implementation of Assessment for Learning in Sweden, Assessment in Education: Principles, Policy \& Practice, 22:1, 104-121.

Kersaint, G., Lewis, J., Potter, R., \& Meisels, G. (2007). Why teachers leave: Factors that influence retention and resignation. Teaching and Teacher Education 23, 775794.

Konur, H., \& Konur, B. (2011). Illköğretim öğretmenlerinin kullandıkları ölçme değerlendirme metotlarına ilişkin görüşleri. Necatibey Eğitim Fakültesi Elektronik Fen ve Matematik Eğitimi Dergisi (NEF-EFMED), 5(2), 138-155.

Knight, P. (2002). A systemic approach to professional development: learning as practice. Teaching and Teacher Education, 18(3), 229-241.

Konur, H., \& Konur, B. (2011). İlköğretim öğretmenlerinin kullandıkları ölçme değerlendirme metotlarına ilişkin görüşleri. Necatibey Eğitim Fakültesi Elektronik Fen ve Matematik Eğitimi Dergisi (NEF-EFMED), 5(2), 138-155.

Landis, R., Edwards, B. D., \& Cortina, J. (2009).“Correlated residuals among items in the estimation of measurement models". In C. E. Lance \& R. J. Vandenberg (Eds.). Statistical and methodological myths and urban legends: Doctrine, verity, and fable in the organizational and social sciences (pp. 195-214). New York: Routledge.

MacCallum, R.C., Browne, M.W., Sugawara, H.M. (1996). Power Analysis and Determination of Sample Size for Covariance Structure Modeling. Psychological Methods, 1:130-49.

MoNE, (2013). Ilköğretim Kurumları Fen Bilimleri Dersi (3, 4, 5, 6, 7 ve 8. Sınıflar) Öğretim Programı, Ankara: Devlet Kitapları Müdürlüğü.

National Council of Teachers of English. (2013). Formative assessment that truly informs instruction. Urbana, IL: Author. Retrieved from http://www.ncte.org/library/NCTEFiles/Resources/Posi tions/formativeassessment single.pdf

Notani, A. S. (1998). Moderators of perceived behavioral control's predictiveness in the theory of planned behavior: A meta-analysis. Journal of Consumer Psychology, 7, 247-271.

Martin, J.J., \& Kulinna, P.H. (2004). Self-Efficacy Theory and the Theory of Planned Behavior: Teaching Physically Active Physical Education Classes, Research Quarterly for Exercise and Sport, 75:3, 288-297

Martin, J.J., \& Kulinna, P.H. (2005). A social cognitive perspective of physical activity related behavior. Journal of Teaching in Physical Education, 24(3), 265281.

Öz., H. (2014). Turkish Teachers'Practices of Assessment for Learning in the English as a Foreign Language Classroom. Journal of Language Teaching and Research, 5(4), 775-785.

Pajares, M. F. (1992). Teachers' beliefs and educational research: cleaning up a messy construct. Review of Educational Research, 62, 307-332.

Ruiz-Primo, M. A., \& Furtak, E. M. (2007). Exploring teachers' informal formative assessment practices and students' understanding in the context of scientific inquiry. Journal of Research in Science Teaching, 44(1), 57-84

Sadler, D. R. (1998). Formative assessment: Revisiting the territory. Assessment in Education: Principles, Policy \& Practice, 5(1), 77-85.

Schifter, D. E. \& Ajzen, I. (1985). Intention, perceived control, and weight loss: An application of the theory of planned behavior. Journal of Personality and Social Psychology, 49(3), 843-851.

Shepard, L. A. (2000). The role of assessment in a learning culture. Educational Researcher, 297), 4-14. 
Shermis \& Di Vesta (2011). Classroom assessment in action. Lanham, MD: Rowman \& Littlefield Publishers.

Sireci, S. G. \& Berberoğlu, G. (2000). Using bilingual respondents to evaluate translated-adapted items. Applied Measurement in Education, 13(3), 229-248.

Stanec, A. D. S. (2009). The theory of planned behavior: Predicting teachers' intentions and behavior during fitness testing. Journal of Teaching in Physical Education, 28, 255-271.

Stern, T. (2009). The Role of Formative Assessment in Enhancing Independent Learning and Reflective Teaching: Some Results of the Austrian IMST-Project. In K. Subramaniam \& A. Mazumdar (Eds.), Proceedings of the epiSTEME-3-Conference (pp. 209-214). Mumbai: HBCSE Tata Institute of Fundamental Research.

Sumantri, M. S. \& Satriani, R. (2016). The effect of formative testing and self-directed learning on mathematics learning outcomes. International Electronic Journal of Elementary Education, 8 (3), 507524.

Sutton, S. (1998). Explaining and predicting intentions and behavior: How well are we doing? Journal of Applied Social Psychology, 28, 1318-1339.

Sümer, N. (2000). Yapısal eşitlik modelleri. Türk Psikoloji Yazıları, 3(6), 49-74.

Şimşek, Ö. F. (2007). Yapısal eşitlik modellemesine giriş: Temel ilkeler ve LISREL uygulamaları. Ankara: Ekinoks Yayınevi.

Tabachnick, B. G., \& Fidell, L. S. (2013). Using multivariate statistics (6th ed.). Boston, MA: Pearson Education.

Deborah J. Terry, D.J., \& O'Leary, J.E. (1995). The theory of planned behaviour: The effects of perceived behavioural control and self-efficacy. British Journal of Social Psychology, 34, 199-220.

Trumbull, E., \& Lash, A. (2013). Understanding Formative Assessment: Insights from Learning Theory and Measurement Theory. San Francisco: WestEd

Volante, L., \& Beckett, D. (2011). Formative assessment and the contemporary classroom: Synergies and tensions between research and practice. Canadian Journal of Education, 34, 239-255.

Yan, Z. (2014). Predicting teachers' intentions to implement school-based assessment using the Theory of Planned Behaviour. Educational Research and Evaluation, 20, 83-97.

Yan, Z., \& Cheng, E. C. K. (2015). Primary teachers' attitudes, intentions and practices regarding formative assessment. Teaching and Teacher Education, 45, 128-136.
Yau, K. (2004). Teachers' perceptions of assessment for learning (Unpublished master's thesis). University of Hong Kong, Pokfulam.

Yim, Y. S., \& Cho, H.Y. (2016). Predicting pre-service teachers' intention of implementing peer assessment for low-achieving students. Asia Pacific Educ. Rev., 17:63-72.

Young, J.E.C. \& Jackman, M.G.A. (2014). Formative assessment in the Grenadian lower secondary school: teachers'perceptions, attitudes and practices, Assessment in Education: Principles, Policy \& Practice, 21:4, 398-411.

Zint, M. (2002). Comparing three attitude-behavior theories for predicting science teachers' intentions. Journal of Research in Science Teaching, 39(9), 819844.

Wilson, M., \& Draney, K. (2004). Some links between largescale and classroom assessments: The case of the BEAR Assessment System. In M. Wilson (Ed.), Toward coherence between classroom assessment and accountability. The 103rd Yearbook of the National Society for the Study of Education, Part II (pp. 132154). University of Chicago Press.

Woolfolk Hoy, A., Davis, H., \& Pape, S. J. (2006). Teacher knowledge and beliefs. In P. A. Alexander, \& P. H. Winne (Eds.), Handbook of educational psychology. 


\section{Appendix}

Teachers' Conceptions and Practices of Formative Assessment Scale in Turkish Version

\section{A: DUYUŞSAL TUTUM ÖLÇEĞi}

$1 \quad$ Biçimlendirici değerlendirme yapmayı seviyorum.

2 Biçimlendirici değerlendirme zevkli bir süreçtir.

3 Biçimlendirici değerlendirme ilgi çeken bir değerlendirmedir.

4 Biçimlendirici değerlendirme öğretimi daha kolay hale getirmektedir.

$5 \quad$ Biçimlendirici değerlendirme öğrencilerin birbirlerine yardım etmelerini destekler.

6 Biçimlendirici değerlendirme daha iyi bir öğrenme ortamı olmasına yardımcı olur.

7 Biçimlendirici değerlendirme, bu sürece harcayacağım zamana değeceğini düşündüğüm bir değerlendirmedir.

\section{B: TUTUM ÖLÇEĞi}

8 Biçimlendirici değerlendirme öğrencilerin öğrenmeye yönelik merak duygularını arttırabilmektedir.

9 Biçimlendirici değerlendirme, öğrenci performanslarının doğru bir şekilde değerlendirmesini sağlayabilmektedir.

10 Biçimlendirici değerlendirme, öğrenme ve öğretimin birleşmesine yardımcı olabilmektedir

11 Biçimlendirici değerlendirme, öğrencileri daha çok çalışmaya teşvik edebilmektedir.

12 Biçimlendirici değerlendirme öğrencilerin adil bir şekilde değerlendirilmelerine katkıda bulunabilmektedir.

13 Biçimlendirici değerlendirme ile öğrencilerin öğretmenlerinden aldıkları dönütler, öğrencilerin güçlü ve zayıf yönlerini öğrenmelerine yardımcı olabilmektedir.

14 Biçimlendirici değerlendirme öğrencilerin bağımsız öğrenmelerine yardımcı olabilmektedir.

15 Biçimlendirici değerlendirme, öğrencinin öğrenmede kendine olan güvenlerinin artmasına yardımcı olabilmektedir.

16 Biçimlendirici değerlendirme öğrenme-öğretme sürecinin niteliğini arttırabilmektedir.

17 Biçimlendirici değerlendirme öğretimde verimliliği arttırabilmektedir.

\section{C: ÖZNEL NORM ÖLÇEĞi}

Bildiğim kadarıyla, aşağıda belirtilen paydaşlar biçimlendirici değerlendirmenin kullanılmasının önemli olduğunu düşünürler.

18 Milli Eğitim Bakanlığı'na bağıı çalışan memurlar.

19 Okulumun müdürü.

20 Öğrencilerimin velileri.

21 Öğrencilerim.

22 Meslektaşlarım.

\section{D: KONTROL EDILEBILIRLIK ÖLÇEĞ}

23 Biçimlendirici değerlendirmeyi ne kadar sıklıkta uygulayacă̆ıma ben kendim karar verebilirim.

24 Biçimlendirici değerlendirmeyi ne zaman uygulayacağıma ben kendim karar verebilirim.

25 Biçimlendirici değerlendirmeyi uygulayıp uygulamayacağıma ben kendim karar verebilirim.

26 Biçimlendirici değerlendirmede uygulayacağım yönteme ben kendim karar verebilirim.

\section{E: ÖZ-YETERLIK ÖLÇEĞi}

27 Biçimlendirici değerlendirmeyi öğrenme-öğretme süreciyle birleştirebilirim.

28 Biçimlendirici değerlendirmeyi uygulamaya yönelik yeterli eğitimi aldım. 
29 Biçimlendirici değerlendirme etkinlikleri oluşturabilirim.

30 Biçimlendirici değerlendirmeyi uygulamaya yönelik gerekli zamanı oluşturabilirim.

31 Biçimlendirici değerlendirmeyi uygulamaya yardımcı materyallere (CD, DVD, el kitabı gibi) sahibim.

32 Biçimlendirici değerlendirmeyi uygulayabilmek için gerekli becerilere sahibim.

\section{F: NIYET ÖLÇEĞi}

33 Biçimlendirici değerlendirme uygulamalarını denemek istiyorum.

34 Biçimlendirici değerlendirmeyi öğretimle birleştirmek istiyorum.

35 Uygun biçimlendirici değerlendirme etkinlikleri oluşturmak istiyorum.

36 Biçimlendirici değerlendirmeye yönelik ölçme ve değerlendirme yöntemlerini belirlemek istiyorum.

37 Biçimlendirici değerlendirmeyi uygulama konusunda gerekli çabayı göstereceğimi düşünüyorum.

38 Öğrencilerimi biçimlendirici değerlendirmeye katılımları konusunda cesaretlendirmek istiyorum.

\section{G: DAVRANIŞ ÖLÇEĞi}

39 Biçimlendirici değerlendirmeyi son altı ay içinde uyguladınız mı?
1 ( ) Her gün
2 ( ) Neredeyse hergün
3( ) Çoğu gün
4 ( ) Bazı günler
5 ( ) Hiçbir zaman

40 Biçimlendirici değerlendirmeyi öğretim sürecinde son altı ayda ne kadar sıklıkta kullandınız?

1( ) Çok sık 2 ( ) Sıklıkla $\quad 3$ ( ) Çoğu gün $\quad$ 4( ) Bazı günler 5 ( ) Hiçbir zaman

